appendix, or gall-bladder, disease of any of these being commonly associated with gastric ulcer. More rarely such a source may be elsewhere-for example, tonsils or nose."

I quote from the British Medical Journal of Feb. 11th and have put several sentences in italics as I consider them important.

The above remarks comprise apparently all that is known of any importance about the causation of gastric ulcer, and if the statement is correct that a gastric ulcer is due to the local effects on the stomach of bacteria produced in another part of the body, any procedure that merely involves operative interference with the stomach and does not remove the cause of the ulcer leaves that cause still in action. Therefore. as in only a very small proportion of cases is the so-called cause removed, the treatment adopted is neither scientific nor surgical. If this description of the causation of gastric ulcer be true, the obvious treatment should be the removal of the source of infection of the gall-bladder, appendix or tooth and the excision of the ulcer. There can clearly be no indication to interfere with the mechanics of the stomach, unless of course there is any pyloric obstruction. Again, I would ask why are infections of the teeth, appendix, or gall-bladder commonly assuciated with gastric ulcer? What are the causes which determine infection of the appendix, gall-bladder and teeth? The reason is obviously because they play a part in the sequence of which gastric ulcer is merely one result. Do gastric or duodenal ulcers ever occur in a gastro-intestinal canal which is otherwise normal? Perhaps some experienced pathologist will answer this question. Personally, I know they do not.

Turning now to the remarks of that master of surgical technique, Sir Berkeley Moynihan, who said that "with almost everything which had been advanced by Sir $W$. Hale-White he found himself in complete agreement" - his experience has led him to come "to the conclusion that the only operation which was worth while in the great majority of cases was partial gastrectomy." The position, then, is this-namely, that the medical profession, as represented by those whose ouinion and judgment are regarded as most valuable and reliable, consider that while the cause of gastric ulcer" is due to the local effect on the stomach of bacteria or toxins in another part of the body," the scientific treatment of this condition is to remove as much of the stomach as the skill of the surgeon will permit him to do with safety. As, however, the bacteria or toxins are still in action, the logical conclusion which this treatment suggests is that if the entire stomach is removed, gastric ulcer can no longer be produced by them. Are we sure that in concentrating on what I believe to be an end-result in a sequence, surgeons are not neglecting completely the treatment of the factors which produce the ulcer and which are still operative?

I am, Sir, yours faithfully,

Feb. 11th, 1922.

W. ARBUTHNOT ILANE.

CONTROL OF VENEREAL DISEASE : THE CAMPAIGN IN GERMANY.

To the Elitor of THE LANCEr.

Sin,-The very valuable report on the anti-venereal campaign in Germany, appearing in your issue of Feb. 11th, referring to the nineteenth annual meeting of the Deutsche Gesellschaft zur Bekämpfung der Geschlechtskrankheiten, concludes with the following sentence : "It will be seen from this summary of the proceedings of the D.G.B.G. that its guiding principles are not identical with those of the National Council for Combating Venereal Diseases." These principles, however, appear to be identical with those of the Society for the Prevention of Venereal Disease in regard to immediate self-disinfection, Prof. Blaschko insisting on the very points so often raised by the Society for the Prevention of Venereal Disease, "as to the necessity of deciding on a simple, cheap, and efficient disinfectant, and that personal prophylaxis is eminently a private matter." The D.G.B.G. also complains that .6 the chief concern of legislation in Germany has been to put as many hindrances in the way as possible", and clearly shares with the Society for the Prevention of Venereal Disease a similar difficulty in obtaining Government support.

Prof. Blaschko's remarks as regards ablution centres are very interesting, and he advocates their use in large towns, because " in addition to the immediate benefit obtained by ablution there is the teaching of personal prophylaxis, so that a man who has been twice or thrice to such a centre learns how to disinfect himself.'

This report of the leading German authorities is particularly interesting, in view of the suggestion widely circulated by Lord Gorell and the National Council for Combating Venereal Diseases, that the German delegates at the Red Cross Conference at Copenhagen last May were opposed to immediate selfdisinfection: whereas it is quite clear that on the contrary authoritative medical opinion in Germany sees almost eye to eye with the Society for the Prevention of Venereal Disease, and has to contend with similar "objections raised in certain quarters by women." although in this country, where women are more progressive, and take a larger share in politics and social movements than in Germany, an influential section of women support the policy of immediate self-disinfection for men.

I am, Sir, yours faithfully,

H. WaNsey Bayly,

Harley-streot, W., Feb. 11th, 1922. Hon. Sec., S.P.V.D.

\section{AID TO MEX OF LETTERS AND SCIENCE IN RUSSIA.}

To the Editor of THE LANCET.

SIR,- At the beginning of last year a British Committee was formed with the object of sending books and other publications to men of letters and science remaining in Russia. The Committee was assured that any such works, if addressed to the House of Science, or the House of Literature and Art, in Petrograd, would reach their destination and would be much appreciated by literary and scientific men who met there and were cut off from the intellectual life of the rest of the world.

An appeal was, therefore, made for funds to purchase works of a non-political type for dispatch to Petrograd, and Prof. Oldenburg, Permanent Secretary of the Acaderny of Sciences, furnished a list of books and other publications much needed by Russian savants. The books particularly desired were those which included accounts of current problems and developments of pure and applied science. As the result of this appeal, the sum of $\mathfrak{E} 44817 \mathrm{~s}$. $5 d$. was subscribed, and several scientific societies, including the Royal Society, entrusted the Comnuittee with their publications for transmission to Petrograd. The Russian Trade Delegation undertook the dispatch of the books, and 10 cases hare been forwarded.

Prof. Oldenburg, writing on Dec. 21st last, expresses the deepest gratitude of scientinic workers in Petrograd for this stimulating intellectual aid, and says that they have been placed in a special reading-room at the House of Sarants, where they are consulted by a largo number of students throughout the day and have been the means of reviving scientific interests and work. He sends the most cordial thanks of men of science in the city to all who have contributed towards the stimulus to scientific investigation which the new publications have given them.

Having thus established contact with scientific men in Russia and enlightened them as to the progress of research from which they have been separated by political circumstances beyond their control, the Committee is of the opinion that its task has been accomplished. Of the fund remaining in its hands, the sum of $\& 50$ has been expended upon books desired by the University of Latvia, and a small balance will be handed over to the Universities Committee of the Imperial War Relief Fund.

The Committee gratefully acknowledges the generosity of the response to its appeal and believes that the intellectual relief thus afforded will do much 
to strengthen Russian scientific life. A statement of accounts, audited by Messrs. W. A. Browne and Co. chartered accountants, will be sent to anyone who desires a copy.-We are, Sir, yours faithfully, R. A. Gregory, Chairman, C. Hagberg Wright,

Hon. Sec. and Treasurer, The British Committee for Aiding Men of Letters and Scienco in Russia. British Science Guild, 6, John-street, W.C. Feb. 11 th, 1922.

QUEEN ALEXANDRA SANATORIUM AND THE ALPINE TREATMENT OF 'TUBERCULOSIS. To the Editor of THE LANCET.

SIR,-Sir Martin Conway in his letter in your issue of Feb. 11th under the title Alpine Treatment of Tuberculosis is mistaken in thinking that funds from the sale of the Queen Alexandra Sanatorium "are in the hands of its Committee." The sale in question has not yet been carried out, nor has the Council yet considered the question of the application of the proceeds. The sanatorium was closed owing to the difficulty of conveying civilian invalids through France to Switzerland, and of securing proper food and heating. After the war it was not reopened. This was by no means from any loss of confidence in the curative virtues of the Davos climate or in the value of our sanatorial treatment, but solely because the general rise in salaries and wages and in the cost of living, coupled with the advirsr Swiss exchange, would have necessitated charging a much higher fee than could have been paid by the patients of small means for whose benefit subsrriptions were originally raised and the sanatorium was built and equipped.

We are, Sir, yours faithfully,

$$
\begin{aligned}
& \text { D. VeSEY. } \\
& \text { Wh. EWART, M.D., }
\end{aligned}
$$

\section{AN INCOME-TAX ANOMALY.}

To the Editor of THE LANCET.

SIR,-During the war, and especially in the early years, many medical men were employed by the British Red Cross Society and were given honorary rank in the R.A.M.C. by the War Office. These individuals were compelled to pay income tax at the civilian rate. Many of them, myself among them, protested but were overruled. I have now learnt accidentally that the Government relented on this point and decided that the income tax should be charged at the military rate. But the information was not brought to the notice of those who were most concerned.

I am further informed that any application from me cannot be entertained owing to lapse of time. (I was in the employment of the B.R.C.S. from 1914 to March, 1917.) But if $I$ am in a position to have a question raised in the House of Commons, something might be done. I ask you to publish this letter in the hope that it will catch the eye of anyone whose service with the B.R.C.S. began in 1914. - I am, Sir, yours faithfully,

Talbot-square, Hyde Park, Feb. 12th, 1922

$$
\text { Charles Mililer. }
$$

\section{SURGICAL MEASURES IN HYPOPITUITARISM.} To the Editor of THE LANCET.

SIR,-My attention has been drawn to what appears to be a discrepancy between a statement in the review of the Dictionary of Practical Medicine published in THE LANCET of Dec. 10th, 1921, and what I actually wrote in my article on the Affections of the Pituitary in this Dictionary. The passage to which I refer in The LANCET is as follows: "It is curious to note that although operation is advised in some cases of hyperpituitarism, no such form of treatment is even suggested where there is a deficiency in the function of this gland." However, in my article I stated, "Surgical measures may be required in cases of hypopituitarism due to a tumour that is causing local disturbance by pressure."-I am, Sir, yours faithfully, Weymouth-street, W., Feb. 7th, 1922. G. E. BEAUMONT.

$*_{*}^{*}$ We much regret the error.--Fo. L.

\section{attedical âdelos.}

University of Oxford : Radcliffe Prize, 1923.This prize, which is of the value of $\mathfrak{2 5 0}$, will be awarded by the Master and Fellows of University College upon the report of the examiners, provided a sufficiently deserving memoir be submitted for adjudication, for a memoir, or papers, embodying research in any branch of medical science comprised under the following heads : human anatomy, physiology, pharmacology, pathology, medicine, surgery, obstetrics, gynzecology, forensic medicine, hygiene. The prize is open to all graduates of the University who have proceeded, o are proceeding, to a medical degree in the University. Candidates, at the date of application, shall not be Radcliffo Fellows ; but the provision that candidates shall not have exceeded 12 ycars from the date of passing the last examination for the degree of B.A. is upon this occasion so far suspended as to enable any graduate, who was eligible during the years of the war $(1915,1917,1919)$ to be eligible for the next ensuing award (1923). Candidates are required to send in their memoirs to the Assistant Registrar on or before Friday, Dec. 1st, 1922. No memoir for which any University prize has been already awarded can be admitted to competition, nor may the prize be awarded more than once to the same candidate. Tuesday, March 20th, 19:3, is the intended date of the award.

The Romanes Lecture 1923 will be delivered by Prof. Arthur Stanley Eddington, F.R.S., on May 24th, at 6 P.Mr.. the subject being the Theory of Relativity and its Influence on Scientific Thought.

UNIVERSITX of LONDON.-The following new chairs have been instituted : University chair of Bacteriology tenable at University College Hospital Medical School; University chair of Surgery tenable at St. Mary's Hospital Medical School. Applications are also invited for the vacant chair of Physiology tenable at St. Bartholomew's Hospital Medical College.-Sir William Collins will represent the University at the Congress of the Royal Sanitary Institute to be held at Bournemouth in July, 1922. - Students who have passed the Second Examination for Medical Degreest (Part II.) will in future be exempted from examination in physiology at the Intermediate Examination in Science.Prof. A. D. Waller, F.R.S., was re-elected director, and Dr. T. D. Lister treasurer of the Physiological Laboratory untik the end of the session 1921-22.

Candidate's Fees.--(1) The following increases in fees were approved for medical examinations held after Sept. 1st, 1922 : Second Medical Examination, Part I., from 2 to 3. guineas ; Second Medical Examination, Part II., from 8 to 9 guineas; M.B., B.S. Examination from 10 to 12 guineas (either group 6 guineas). (2) It was resolved that an additional fee of $f 11 s$. be charged to a candidate who takes the Fxternal Final Pass Examination instead of honours after having taken his subsidiary honours subject.

Lectures in Pharmacology.-A course of four lectures on Some Recent Developments in Pharmacology will be given by Dr. H. H. Dale, F.R.S., at the I,ondon (R.F.H.) School of Medicine for Women, Hunter-street, London, W.C., on Wednesdays, Feb. 22nd, March 1st, 8th, and 15th, at 5 P.M. The chair at the first lecture will be taken by Prof. Fred Ransom. The syllabus is as follows: Lect. 1, Ergot; Lect. 2, Capillary Poisons ; Lect. 3, Alkaloids for Cinchona and Ipecacuanha; Lect. 4, Artificial Specific Remedies. The lectures, which will be illustrated by lantern slides and accompanied by practical demonstrations, are addressed to students of the University and others interested in the subject. Admission is free without ticket.

UNIVERSITY of SHeFFIELd. - The Council at its last meeting made the following appointments: $\mathrm{Mr}$. A. J. Saxton, M.Sc. Sheffield, to be Assistant Lecturer in Physies: Mr. L. W. Cole, B.Sc. Lond., to be Assistant Lecturer and Demonstrator in Botany. Dr. H. W. Southgate to br Lecturer in Pharmacology. Mr. E. F. Finch and Dr. V. Townrow to be Assistant Curators of the Pathological Musenm. Dr. A. G. Yates to be Demonstrator in Medical Pathology.

In examinations recently held the following candidates were successful :-

Finol M.B., Ch.R.-Hyman Finklestone and Mary P. Gell

Diplome in Pulitic Mealth.-Dorothy E. Mathews and John

Royal Faculty of Puysicrans and Surgeons, GLAsGow.- At an examination held recently the following were admitted as Fellows of Faculty :-

Matthew White, M.A., M.B., Ch.B., Glasgow ; Purnananda Roy, M.B. (Calcut ä Univ.), Calcutta. 